\title{
Studies on the dung-breeding flies in Japan \\ IV. The immature stages of three muscine species occurring from wild brown bear dung (Diptera: Muscidae, Muscinae)
}

\author{
Mitsuhiro Iwasa* and Yutaka Nishijima** \\ *Department of Medical Zoology, Faculty of Medicine, Tokyo Medical and Dental University, \\ 1-5-45, Yushima, Bunkyo-ku, Tokyo 113, Japan \\ **Laboratory of Insect Natural History in Hokkaido, 6-9-3, Shirakaba, Chitose, Hokkaido 066, Japan
}

(Received: April 11, 1984)

Key words: Muscinae, immature stages, wild brown bear dung, Pyrellia tateyamensis, Mesembrina resplendens, Huckettomyia ivatanabei.

\begin{abstract}
The immature stages of three muscine species, Pyrellia tateyamensis Shinonaga, Mesembrina resplendens Wahlberg and Huckettomyia watanabei Pont et Shinonaga, occurring from wild brown bear dung were newly described and their characteristics of taxonomic and biological significance were discussed. The third instar larva of $P$. tateyamensis was of typical Muscini-type, and can be distinguished from those of the known Dasyphora-larva in having a pair of extraanal papillae. This larva also differs from that of $P$. cadaverina (Linnaeus) in the characteristics of posterior spiracles. The larval mode of life of $M$. resplendens was trimorphic obligatory coprophagous. The third instar larva of resplendens is partially related to those of Hydrotaeini and Phaoniinae-Mydaeinae, and can be distinguished from that of a Palaearctic species, $M$. meridiana Linnaeus in having doubled number of branches on anterior spiracles and by the characteristics of posterior spiracles, but extremely resemble that of $M$. mystacea Linnaeus described from Russia. Egg of $H$. watanabei was of typical muscine-type, but the larval characteristics have a close relationship to those of Phaoniinae and Mydaeinae. The third instar larva of this species seems to be facultative carnivorous.
\end{abstract}

\section{INTRODUCTION}

Nishijima and Iwasa $(1979,1984)$ reported

* Present address: Laboratory of Entomology, Obihiro University of Agriculture and Veterinary Medicine, Obihiro, Hokkaido 080, Japan. 岩佐光啓: (現住所) 带広畜産大学畜産環境学科 昆虫学教室 (下080 带広市稲田町)

**西島 浩: 北海道昆虫自然史研究炣 (开066 千藏 市白樺 6-9-3) on the flies occurring from dung of wild brown bear, Ursus arctos Lydekker, in Hokkaido, Japan. These flies exclusively occur in mountainous areas, and their immature stages have not been known until now. Recently we got the immature stages of three muscine-species, namely $P$. tateyamensis, $M$. resplendens, and $H$. watanabei, occurring from brown bear dung. In the present paper, we report on their immature stages and discuss on some characteristics of taxonomic and biological significance. 

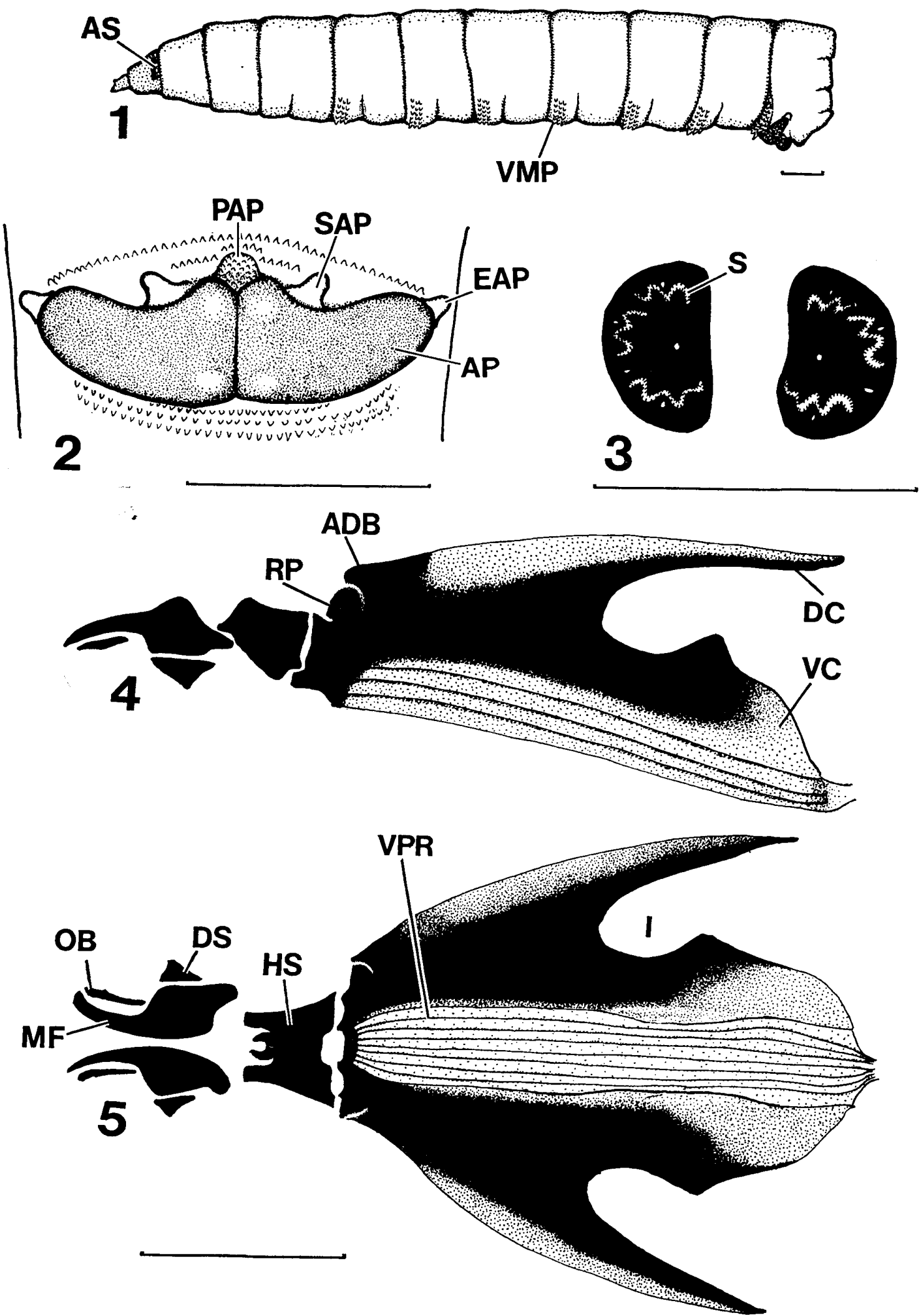

Figs. 1-5 Third instar larva of Pyrellia tateyamensis 1: lateral view, 2: anal plate, ventral view, 3: posterior spiracles, posterior view, 4: cephalopharyngeal sclerite, lateral view, 5: ditto, dorsal view in unfolded condition.

Sacle: $0.5 \mathrm{~mm}$. 


\section{Materials And Methods}

The adult females of $P$. tateyamensis and $M$. resplendens were collected at Kamisatsunai of the foot of Hidaka mountain ranges. While those of $H$. watanabei were collected at Mt. Koikakushu-satsunai of the same mountain ranges. The immature stages were obtained and observed by the methods described by Iwasa (1983).

\section{Pyrellia tateyamensis Shinonaga, 1976} (Figs. 1-5)

\section{Pyrellia tateyamensis Shinonaga, Jap. J.} Sanit. Zool., 27: 423.

Third instar larva. Fully mature larra about $10 \mathrm{~mm}$ in length; yellow color; anterior margins of 6 th to 11 th segments with microscopic ventral papillae (Fig. 1); anal plate slightly protuberant and pigmented with brown; subanal papillae developed; postanal papillae also developed and with microscopic spines; extra-anal papillae present (Fig. 2); anterior spiracle with 8 to 9 branches; spiracular stalks of posterior spiracles not projected; posterior spiracular plate black except slits; slits yellow and distinctly sinuated (Fig. 3); button only a very small yellow spot; mouth hooks of cephalopharyngeal sclerite asymmetrical, pointed in left side and rounded in right side apically; accessory sclerites consist of only oral bars; dental sclerites completely separated ventrally (Fig. 5); pharyngeal sclerite comparatively massive in lateral view; rounded process present under the anterodorsal bridge; rentral cornua slightly longer than dorsal cornua; incision about half length of pharyngeal sclerite; pharyngeal floor transparent and with 7 ventral pharyngeal ridges which are completely developed towards posterior part (Fig. 5).

\section{Mesembrina resplendens Wahlberg, 1844} (Figs. 6-17)

Mesembrina resplendens Wahlberg, Oefiers. K. Vet. Akad. Forhandl., 1: 66.

Egg. Large size, about $3.5 \mathrm{~mm}$ in length and $0.8 \mathrm{~mm}$ in width; white color and typical muscine-type; chorion surface with a reticu- lation of hexagonal meshes; hatching strip of concave surface without hexagonal meshes (Fig. 6).

First instar larva. About 3 to $4 \mathrm{~mm}$ in length; white color; anterior margins of 5 or 6th segments to 11 th segments each with black ventral spinose band (Fig. 7); anterior spiracles not distinct, but slightly visible: posterior spiracles very small and heart-shaped (Fig. 9); cephalopharyngeal sclerite undeveloped and weakly sclerotized (Fig. 8).

Second instar larva. About $6 \mathrm{~mm}$ in length; white color; anterior margins of 6 th to 12 th segments each with ventral spinose band; anterior spiracles distinct; posterior spiracles with 2 slits (Fig. 11); mouth hooks, accessory sclerites and dental sclerites of cephalopharyngeal sclerite distinctly developed; pharyngeal sclerite weakly pigmented, and both cornuae undeveloped (Fig. 10).

Third instar larva. Large size, fully mature larva about 14 to $15 \mathrm{~mm}$ in length: yellow color; anterior margins of 7 th to 12 th segments with microscopic ventral papillae (Fig. 14); anal plate slightly protuberant, subanal papillae developed; postanal papillae also developed and with many microscopic spines; extra-anal papillae present (Fig. 15); anterior spiracle with 9 branches; spiracular stalks of posterior spiracles slightly projected and black; posterior spiracular plates brownish, darkened marginally; slits gently sinuated (Fig. 16); button small; mouth hooks of cephalopharyngeal sclerite slightly asymmetrical, sharply pointed in left and slightly rounded in right apically (Fig. 13); accessory sclerites consist of anterior ribbons and oral bars; dental sclerites not joined by a median ventral arch, but closely apposed ventrally; hypostomal sclerites not slender; pharyngeal sclerite comparatively thick in lateral view; rounded process present under the anterodorsal bridge; ventral cornua slightly longer than dorsal cornua; incision deep, beyond the half length of pharyngeal sclerite (Fig. 12); pharyngeal floor transparent, and with 7 ventral pharyngeal ridges (Fig. 13).

Puparium. Barrel-shaped, broadest at the center and thin in 1st and 2nd segments; about $9 \mathrm{~mm}$ in length; reddish brown color; posterior spiracular plates black; respiratory horns black and small (Fig. 17). 

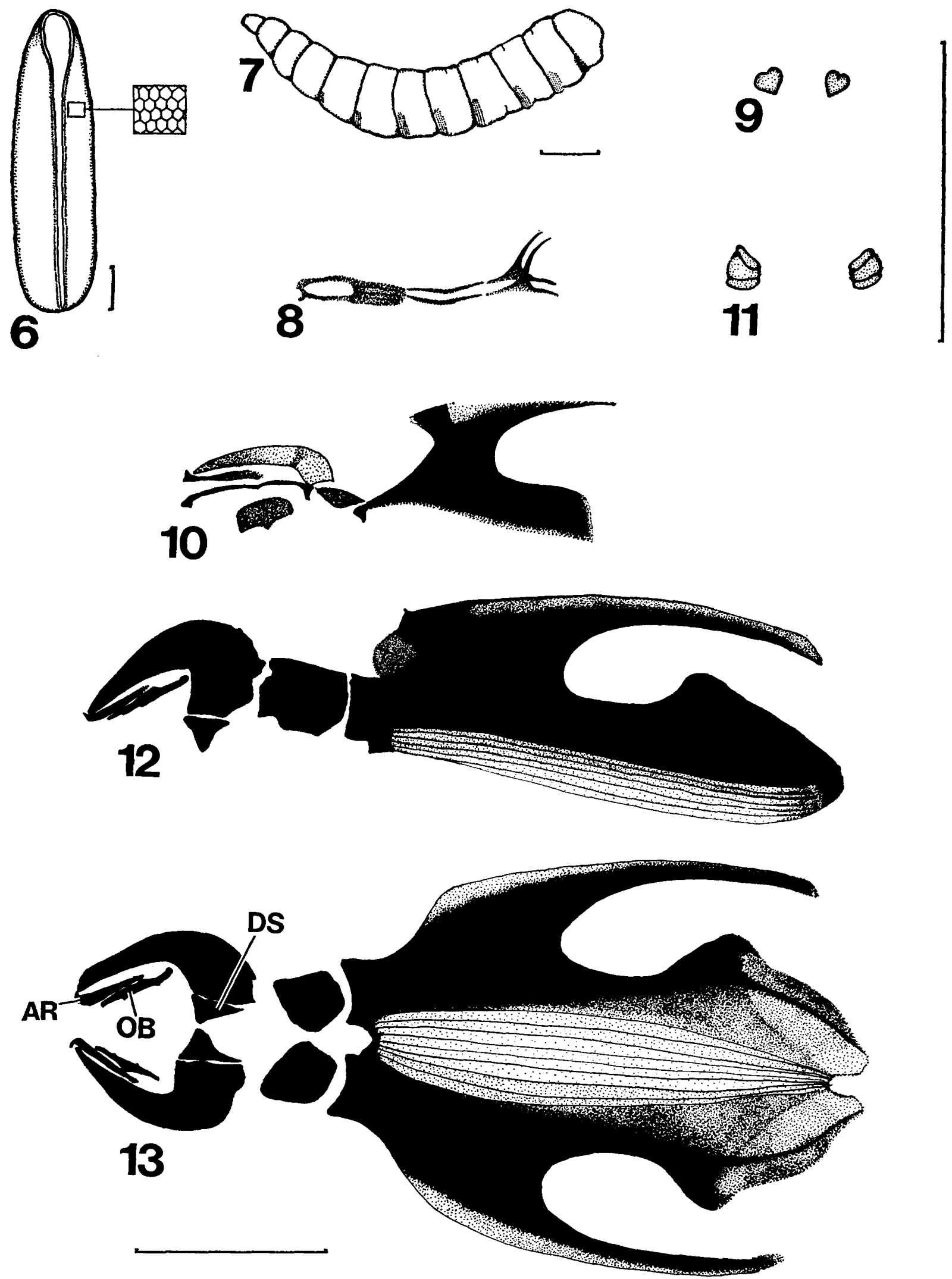

Figs. 6-13 Mesembrina resplendens 6: egg, 7: first instar larva, lateral view, 8: cephalopharyngeal sclerite of first instar larva, lateral view, 9: posterior spiracles of first instar larva, posterior view, 10: cephalopharyngeal sclerite of second instar larva, lateral view, 11: posterior spiracles of second instar larva, posterior view, 12: cephalopharyngeal sclerite of third instar larva, lateral view, 13: ditto, dorsal view in unfolded condition.

Sacle: $0.5 \mathrm{~mm}$. 


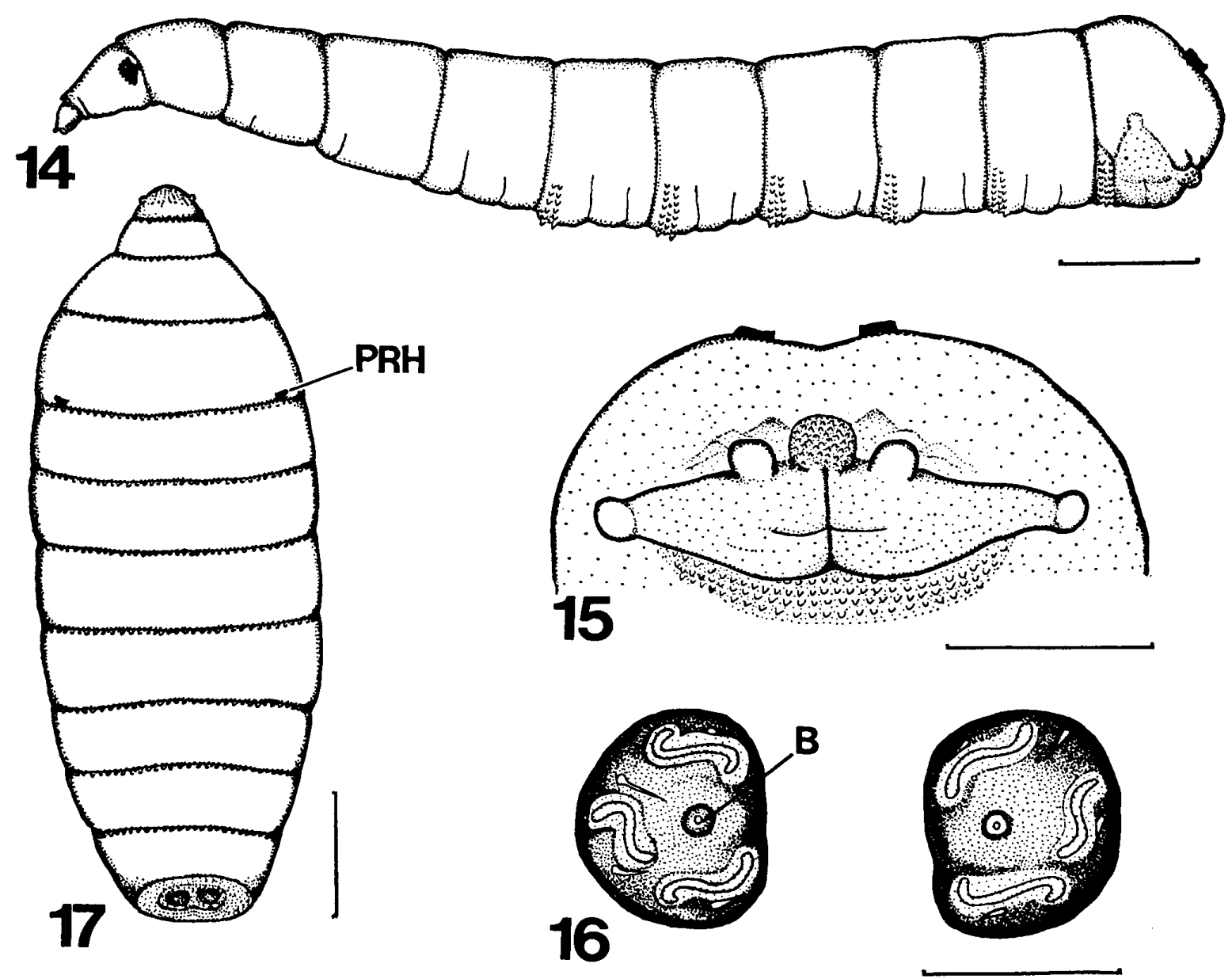

Figs. 14-17 Mesembrina resplendens 14: third instar larva, lateral view, 15: 12th segment of third instar larva, ventral view, 16: posterior spiracles of third instar larva, posterior view, 17: puparium, dorsal view.

Scale: $1 \mathrm{~mm}$ (except Fig. 16 which is $0.25 \mathrm{~mm}$ ).

\section{Huckettomyia watanabei Pont et Shinonaga, 1970}

(Figs. 18-26)

Huckettomyia watanabei Pont et Shinonaga, Jap. J. Sanit. Zool., 21: 193.

Egg. About $2 \mathrm{~mm}$ in length, $0.7 \mathrm{~mm}$ in width; white color; muscine-type; chorion surface with a reticulation of hexagonal meshes except hatching strip (Fig. 18).

First instar larva. Only exuvium was obtained by dissection of unhatched egg. Anterior margins of 5 th to 12 th segments ventrally with black spinose bands; cephalopharyngeal sclerite vestigial (Fig. 20).

Second instar larva. Material was also obtained by dissection of an unhatched egg. About $1.7 \mathrm{~mm}$ in length; white color; cephalopharyngeal sclerite undeveloped and weakly pigmented (Fig. 21) ; posterior spiracles very small and heart-shaped.

Third instar larva. Medium size, fully mature larva about $10 \mathrm{~mm}$ in length; yellow color; 6 th to 12 th segments each with microscopic ventral papillae (Fig. 22); 12th segments slender posteriorly; anal plate slightly protuberant; anal papillae undeveloped; subanal and postanal papillae developed; extra-anal papillae developed into 2 pairs (Fig. 23); anterior spiracle with 5 to 6 branches; posterior spiracular plates brownish; slits gently sinuated (Fig. 24); button comparatively large; mouth hooks of cephalopharyngeal sclerite slightly asymmetrical (Fig. 26); accessory sclerites consist of anterior ribbons, oral bars and posterior ribbons; dental sclerites closely apposed ventrally (Fig. 26); hypostomal sclerite not slender; pharyngeal sclerite slender in lateral 

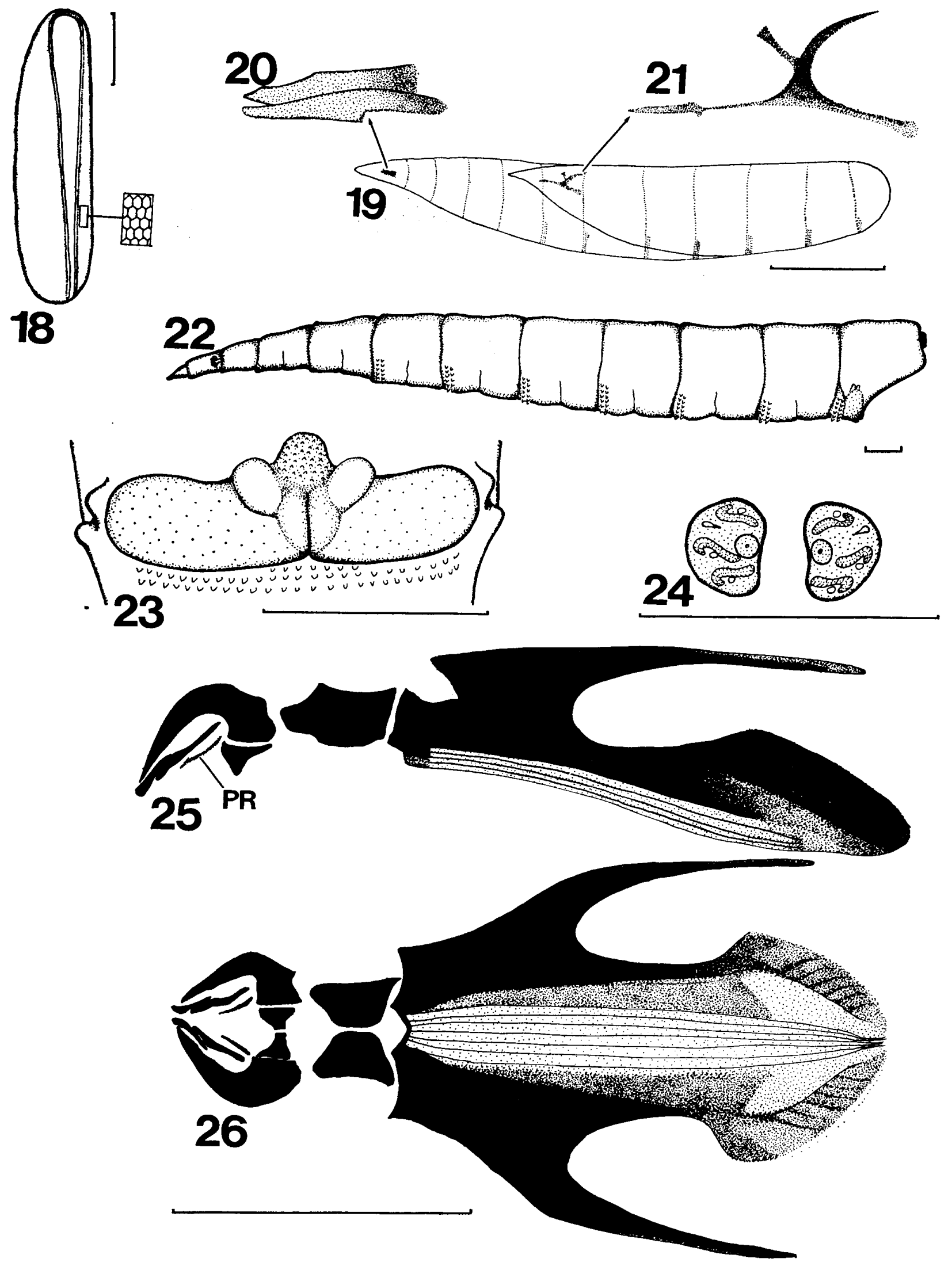
view; incision deep, beyond the half length of pharyngeal sclerite (Fig. 25); ventral cornua longer than dorsal cornua; pharyngeal floor transparent and with 7 ventral pharyngeal ridges (Fig. 26).

\section{Discussion}

The larvae of the genus Pyrellia have been described in only 2 species, $P$. cadaverina Linnaeus by Portchinsky (1910) and Zimin (1948), and $P$. tasmaniae Macquart by Ferrar (1979). The larvae of cadaverina are known to breed in horse dung, while those of tasmaniae were reared from wambat dung in Australia (Ferrar, 1979). The larvae of tateyamensis are considered to mainly breed in brown bear dung and the food habit is obligatory coprophagous as well as those of cadaverina and tasmaniae.

The genus Pyrellia is placed in the tribe Muscini of Muscinae and closely related to the genera Dasyphora and Orthellia. But there are some taxonomic problems among these genera. Skidmore (1973b) paid attention to the oral bars of cephalopharyngeal sclerite in his work of muscid larvae, and suggested that 2 Dasyphora-species, cyanicolor (Zetterstedt) and cyanella Meigen whose larvae have the oral bars should be transferred to the Pyrellia whose larvae have the oral bars, restricting Dasyphora to those species which lack the oral bars as in Musca. The larva of tateyamensis also have the oral bars. But Ferrar (1979) noted that the larva of tasmaniae lack the oral bars. In the Japanese Orthellia-larvae, Shinonaga and Kano (1973) recognized the oral bars in 4 species, but didn't in 1 species. The oral bars are variably distributed and seem to be of less taxonomic value among the three genera, Pyrellia, Dasyphora and Orthellia. Moreover, Skidmore (1973b) separated the Orthellia-larvae from Pyrellia-larvae by lacking the rounded process on pharyngeal sclerite in his key. But Ferrar (1979) doubted the taxonomic value of this process. In fact, Shinonaga and Kano (1973) found the rounded process in all Japanese Orthellialarvae. It seems that there is no discriminative characteristics between Pyrellia- and Orthellia-larvae. The known third instar larvae of Pyrellia including tateyamensis differ from those of the known three Dasyphora-larvae, cyanicolor, cyanella and asiatica by having a pair of extra-anal papillae. The third instar of tateyamensis also can be distinguished from that of cadaverina by the characteristics of posterior spiracles. The larvae of Pyrellia are of typical Muscini-type in the following characteristics: completely separated dental sclerites, distinctly asymmetrical mouth hooks, accessory sclerites consist of only oral bars, massive pharyngeal sclerite, shallow incision, a considerable number of branches of anterior spiracles, radically sinuated slits of posterior spiracles.

The larvae of the genus Mesembrina have been reported in 2 species, $M$. meridiana and $M$. mystacea. The former has been described by Portchinsky (1910), Keilin and Tate (1930) and Thomson (1937), and the latter has been described by Portchinsky (1910, 1911) and Keilin and Tate (1930). Portchinsky (1910) and Séguy (1923) regarded the larvae of meridiana as being

Figs. 18-26 Huckettomyia watanabei 18: egg, 19: larva obtained by dissection of egg, lateral view, 20: cephalopharyngeal sclerite of first instar larva, lateral view, 21: cephalopharyngeal sclerite of second instar larva, lateral view, 22: third instar larva, lateral view, 23: anal plate of third instar larva, ventral view, 24: posterior spiracles of third instar larva, posterior view, 25: cephalopharyngeal sclerite of third instar larva, lateral view, 26: ditto, dorsal view in unfolded condition.

Scale: $0.5 \mathrm{~mm}$.

\section{Abbreviations Used in Figures}

$\mathrm{ADB}$, anterodorsal bridge; $\mathrm{AP}$, anal plate; $\mathrm{AR}$, anterior ribbon; $\mathrm{AS}$, anterior spiracle; $\mathrm{B}$, button; DC, dorsal cornua; DS, dental sclerite; EAP, extra-anal papilla; HS, hypostomal sclerite; I, incision; MF, mouth hook; OB, oral bar; PAP, postanal papilla; PR, posterior ribbon; $\mathrm{PRH}$, pupal respiratory horn; $\mathrm{RP}$, rounded process; $\mathrm{S}$, slit; SAP, subanal papilla: $\mathrm{VC}$, ventral cornua; VMP, ventral microscopic papilla; VPR, ventral pharyngeal ridge. 
obligatory coprophagous, but Thomson (1937) suggested that their mode of larval life was facultative carnivorous. The larvae of mystacea were also suspected to have both modes of life of coprophagous and carnivorous by Portchinsky (1910) and Keilin and Tate (1930). In the present observation three instars of resplendens all were obligatory coprophagous.

Dental sclerites of third instar of resplendens are not joined by a median ventral arch, but they are closely apposed ventrally. According to Keilin and Tate (1930) and Thomson (1937), dental sclerites of meridiana are joined by a strong median ventral arch. On the other hand, those of mystacea are joined by a small median ventral arch (Keilin and Tate, 1930). Dental sclerites of the larvae of Muscini such as Musca, Orthellia and Pyrellia are known to be completely separated ventrally. While those of larvae belonging to the Phaoniinae and Mydaeinae are generally joined by a strong median ventral arch. The structure of dental sclerites of Mesembrina-larvae, though that of resplendens seems to be slightly different from those of meridiana and mystacea, shows an intermediate form between Muscini and Phaoniinae-Mydaeinae.

The third instar larva of resplendens can be distinguished from that of meridiana by having twice number of branches on anterior spiracles and by the characteristics of posterior spiracles, but extremely resemble that of mystacea.

Huckettomyia watanabei was placed in the tribe Hydrotaeini of Muscinae as a monotypy by Pont and Shinonaga (1970). Egg of this species is of typical muscine-type, showing reasonable taxonomic situation of this species. A larva obtained by dissection of an unhatched egg is shown in Fig. 19. This larva seems to be 2nd instar larva sheathed by a exuvium of 1 st insatr. Cephalopharyngeal sclerite of 1 st instar left in a exuvium is undeveloped and vestigial (Fig. 20). The 2nd instar may be coprophagous, but the third instar is considered to be facultative carnivorous. Skidmore (1973a) divided the larval life of Muscidae into 4 types, viz. trimorphic saprophagous, trimorphic facultative carnivorous, dimorphic obligatory carnivorous and monomorphic obligatory carnivorous, and included some genera, e.g. Synthesiomyia, Azelia, Dendrophaonia and Ophyra of Hydrotaeini in trimorphic facultative carnivorous type. The larval life of Huckettomyia may be also included in this type. However, if eclosion and ecdysis coinside with each other, it is a dimorphic facultative carnivorous type. Conclusion cannot be drawn in the present observation. The third instar larva of Huckettomyia is close to those of Phaoniinae and Mydaeinae in the following respects: ventrally apposed dental sclerites, indistinctly asymmetrical mouth hooks, accessory sclerites consist of 3 pairs of sclerites, slender pharyngeal sclerite, deep incision, less number of branches of anterior spiracles, gently sinuated slits of posterior spiracles.

In Muscinae, the larvae of Muscini such as Musca, Orthellia, Dasyphora including Pyrellia are of typical Muscini-type and believed to be almost saprophagous. On the other hand, some larvae of Hydrotaeini such as Hydrotaea and Ophyra including Huckettomyia are similar to those of Phaoniinae and Mydaeinae, and considered to be facultative or obligatory carnivorous. Hennig (1956) mentioned that the larvae of Mesembrina and Polietes have the ventrally fused dental sclerites and the developed accessory sclerites like as those of Phaoniinae. Some larvae of Polietes have been observed to be carnivorous by many authors. But Iwasa (1980) reported that the larva of $P$. nigrolimbatus Bonsdorff has the ventrally separated dental sclerites and its food habits is coprophagous. As mentioned above, the food habits of $M$. meridiana and $M$. mystacea were suspected to be carnivorous by some authors. Mesembrina and Polietes are placed in Muscini, but their larvae may have some variety in both food habits and morphological characteristics and represent a transitional form between the typical Muscini and the Hydrotaeini, Phaoniinae-Mydaeinae.

\section{AGKnowledgements}

We wish to express our sincere thanks to Prof. R. Kano and Dr. S. Shinonaga of Tokyo Medical and Dental University for their valuable suggestions and continuous encouragements throughout this work. Our thanks are also due to $\mathrm{Mr}$. K. Kuramochi of Obihiro University and Mr. M. 
Yajima of Ueno Zoological Garden for their kindness in offering the brown bear dung pieces for rearing the larvae.

\section{ReFERENCES}

Ferrar, P. (1979): The immaure stages of dung-breeding muscoid flies in Australia, with notes on the species, and keys to larvae and puparia. Aust. J. Zool., Suppl. Ser., 73: 1-106.

Hennig, W. (1956): Muscidae. In: Die Fliegen der palaearctischen Region (ed., Lindner, E.), Vol. 63b, pp. 906-926, Schweizerbart, Stuttgart.

Iwasa, M. (1980): Descriptions of three species of muscid larvae and eggs newly recorded from cow dung in Japan (Diptera: Muscidae). Jap. J. Sanit. Zool., 31: 53-56.

Iwasa, M. (1983): Studies on the dung-breeding flies in Japan II. Notes on the immature stages of the genus Gymnodia Robineau-Desvoidy (Diptera: Muscidae). Jap. J. Sanit. Zool., 34: 253-262.

Keilin, D. and P. Tate (1930): On certain semicarnivorous anthomyid larvae. Parasitology, 22: 168-181.

Nishijima, Y. and M. Iwasa (1979): Flies occurring from wild brown bear dung in Hokkaido. Jap. J. Sanit. Zool., 30: 355-359.

Nishijima, Y. and M. Iwasa (1984): Additional data on the flies occurring from wild brown bear dung in Hokkaido I. Jap. J. Sanit. Zool., 35: 323-324.

Pont, A. C. and S. Shinonaga (1970): A new genus of Muscidae from Palaearctic East Asia (Diptera: Muscidae). Jap. J. Sanit. Zool., 21 : 193-199.

Portchinsky, I. A. (1910): Recherches biologiques sur le Stomoxys calcitrans L. et biologie comparee des muches coprophagues. Trav. Bureau Entomol. Dept. Agric., 8: 1-90.

Portchinsky, I. A. (1911): Hydrotaea dentipes F. La biologie et la destruction par ses larves de celles de Musca domestica L. Trav. Bureau Entomol. Dept. Agric., 9: 1-30.

Séguy, E. (1923): Dipteres Anthomyides. Faune de France (Paris), 6: 393.

Shinonaga, S. and R. Kano (1973): Studies on the flies occurring from the excrement of pasturing cattle and other hervivorous animals 1 . On the 3rd stage larvae of the genus Orthellia R.-D of Japan (Diptera: Muscidae, Muscinae). Jap. J. Sanit. Zool., 24: 57-63.

Skidmore, P. (1973a): Notes on the biology of
Palaearctic Muscids (1). Entomologist, 106: 25-48.

Skidmore, P. (1973b). Notes on the biology of Palaearctic Muscids (2). Entomologist, 106: 49-59.

Thomson, R. C. M. (1937): Observations on the biology and larvae of the Anthomyidae. Parasitology, 29: 273-358.

Zimin, L. S. (1948): Identification of the larvae of the synanthropic flies in Tadzhikistan. Fauna USSR, 28: 1-112 (in Russian).

$$
\begin{gathered}
\text { 摘 要 } \\
\text { 粪より発生するハエ類の研究 } \\
\text { N. クマの糞より発生するイェバェ亜科 } \\
\text { (Muscinae) の3 種の若齢期について } \\
\text { (双翅目，イエバエ科) }
\end{gathered}
$$

西島・岩佐 $(1979,1984)$ は, ヒグマの糞より発生 するハェ類について報告した。 これらの八エは山地の みに生息することから，それらの若齢期についてはほ とんど知られていない，著者らは，これらのうちイエ バエ要科に属する 3 種, タテヤマコミドリイエバエ Pyrellia tateyamensis Shinonaga, キバネクロバエ Mesembrina resplendens Wahlberg, ワタナベトゲ アシイェバェ Huckettomyia watanabei Pont et Shinonaga の若齢期を新しく記載し, 分類学上㧍よび食 性上重要な形質について論に゙た. タテヤマコミドリイ エバェの 3 龄幼虫は糞食性で, 近縁の Dasyphora 属 とは extra-anal papillae をもつことにより区別でき， 同属のコミドリイエバエ P. cadaverina と後方気 門の特徴により区別できる。キバネクロバエは，1 齢， 2 齢，3齢，とも翼食性で，3龄幼虫は旧北区に生息 する Mesembrina meridiana とは前方気門の数と後 方気門の特徵により区別できるが，ソ連から記載され ている M. mystacea に酷似している. ワタナべトゲ アシイエバエの卯は，典型的なイエバエ亜科型である が，3齢幼虫はトゲアシイエバエ带科やマルハナイエ バェ亜科の幼虫と共通の特徴をもっていた.この種の 2 龄は，糞食性と思われるが，3龄は facultative carnivorous と教えられる。

3 齡幼虫のとくに口鈎の対称性, 付属片や歯板の構 造, 咽頭板の形態 - 構造, 前 - 後方気門などの特徵に おいて，タテヤマミコドリイエバエは典型的なイエバ エ亜科型で，ワタナベトゲアシイエバエはトゲアシイ エバエやマルハナイエバエに近く, キバネクロバェは 両者の中間移行型の特徴を示した。 Mesembrina 属の 他種の幼虫の食性については，同じ Muscini に属す るクロハナイエバェ属 (Genus Polietes) の幼虫と同 様に不明な点が多い. 